\title{
Antarctic krill meal as an alternative protein source in pet foods evaluated in adult mink (Neovison vison). I. Digestibility of main nutrients and effect on reproduction
}

Open Access Animal Physiology

10 February 2015

Number of times this article has been viewed

\author{
Åshild Krogdahl' \\ Øystein Ahlstrom² \\ Lena Burri ${ }^{3}$ \\ Sigve Nordrum ${ }^{3}$ \\ Laurie C Dolan ${ }^{4}$ \\ Anne Marie Bakke' \\ Michael H Penn' \\ 'School of Veterinary Medicine, \\ Norwegian University of Life Sciences, \\ Oslo, Norway; ${ }^{2}$ Department of Animal \\ and Aquacultural Sciences, Norwegian \\ University of Life Sciences, Ås, \\ Norway; ${ }^{3}$ Aker BioMarine Antarctic \\ AS, Oslo, Norway; ${ }^{4}$ Burdock Group \\ Consultants, Orlando, FL, USA
}

Correspondence: Åshild Krogdahl Norwegian University of Life Sciences, School of Veterinary Medicine, Department of Basic Sciences and Aquatic Medicine, PO Box 8I46, Dep NO-0033, Oslo, Norway

Tel +472964534

Fax +472597310

Email ashild.krogdahl@nvh.no
Background: Antarctic krill meal is rich in protein, fat, and omega-3 fatty acids. Two experiments were performed to evaluate nutritional and health aspects of Antarctic krill meal in the diet of reproducing mink to determine whether such a meal can be used as a pet food ingredient.

Materials and methods: The first experiment assessed the digestibility and palatability of Antarctic krill meal. The second investigated effects of four dietary inclusion levels of Antarctic krill meal $(0 \%, 9 \%, 17 \%$, and $35 \%$ of dry matter) on the reproductive performance and health of female mink (16 per group) when substituted for high-quality fishmeal prior to mating through gestation, parturition, lactation, and early kit growth (117 days). The diets are named K0, K9, $\mathrm{K} 17$, and K35, respectively.

Results: Antarctic krill meal showed high protein and fat digestibility ( $85 \%$ and $98 \%$, respectively). No effect of the test material on the reproductive performance of maternal animals was observed. Relative organ weights of maternal animals were the same for the K0, $\mathrm{K} 9$, and K17 groups, whereas K35 animals showed higher values for stomach, intestine, and spleen weights. Likewise, results of hematology, clinical chemistry, and histomorphological analyses did not differ between animals fed with K0, K9, and K17 diets. Animals in the K35 group showed some changes in the liver and gastrointestinal tract, clinical chemistry, and hematology compared to control animals. At weaning, body weight of kits in the K35 group tended to be lower than that of the $\mathrm{K} 0$ group, which may have been related to the larger initial litter size of the K35 group.

Conclusion: Antarctic krill meal has similar nutritional value as high-quality fishmeal and produces no adverse effects in reproducing female mink when included in feed at up to $17 \%$ of dry matter. The results suggest that Antarctic krill meal can be safely included in pet food.

Keywords: Antarctic krill meal, protein source, mink, reproduction, pet

\section{Introduction}

Conventionally, meat, pork, lamb, poultry, and soybean meals are used as protein sources in pet food. ${ }^{1}$ However, krill meal is gaining interest as a source of both protein and omega-3 ( $\omega$-3) fatty acids. Antarctic krill meal is derived from shrimp-like, marine crustaceans, Euphausia superba, that are caught from the wild. These organisms have a circumpolar distribution, with the highest concentrations found in the Southern Ocean. ${ }^{2}$ Besides being composed of high-quality protein, Antarctic krill is also a source of lipids rich in the $\omega-3$ fatty acids eicosapentaenoic acid (20:5n-3) and docosahexaenoic acid (22:6n-3). ${ }^{3}$ Dietary supplementation with $\omega-3$ fatty acids supports 
normal fetal development and is associated with improved health and decreased risk for various diseases. ${ }^{4-8}$ Studies in dogs have shown that supplementation with $\omega$-3 fatty acids helps maintain cardiovascular health, reduce inflammation, alleviate osteoarthritis, and slow the progression of renal disease..$^{9-12}$ Dogs with allergies or skin conditions may also benefit from $\omega-3$ supplementation. ${ }^{13}$ Conversely, a shortage of eicosapentaenoic acid and docosahexaenoic acid in dog food may negatively affect coat luster and shedding and increase behavioral aggression. ${ }^{14,15}$

The health benefits of $\omega-3$ fatty acids from krill have been characterized in various preclinical and clinical studies in the form of krill oil. ${ }^{16-21}$ However, to date, no study has investigated the combination of krill oil and proteins for use in companion animal feeds. The main limitations to high inclusion of krill meals in feeds are the naturally high levels of fluorine and copper. Fluorine is mainly located in the exoskeleton, and its levels can vary in whole krill meal between $1,000 \mathrm{mg} / \mathrm{kg}^{22,23}$ and 2,400 mg/kg (dry weight). ${ }^{24}$ The European Union (EU) currently allows up to $3,000 \mathrm{mg} / \mathrm{kg}$ fluorine in feed materials from marine krill and up to $150 \mathrm{mg} / \mathrm{kg}$ in complete feeds with a moisture content of $12 \% .{ }^{25}$ No such limits have been established by the United States Food and Drug Administration (US FDA). Removal, or partial removal of the exoskeleton can reduce the fluorine content of the meal. ${ }^{26}$ Deshelling will also reduce the chitin content, a long-chain polymer of $N$-acetylglucosamine with similar effects on digestive processes and nutrient utilization as dietary fiber. ${ }^{27}$ In contrast to vertebrates which use hemoglobin, crustaceans such as krill use hemocyanin to transport oxygen and carbon dioxide within the body. ${ }^{28}$ Hemocyanin utilizes copper instead of iron in oxygen transport, ${ }^{28}$ resulting in naturally high copper levels in krill. ${ }^{29}$ Copper is an essential trace element necessary for numerous bodily functions; however, excessive levels can cause toxicity. The EU currently allows up to $25 \mathrm{mg} / \mathrm{kg}$ copper in complete feeds. ${ }^{30}$

The mink, which is a strict carnivore, has become a common model animal for evaluation of quality of feed ingredients for dogs and cats, and precise and accurate procedures have been developed in this species. ${ }^{31-35}$ The results obtained with mink correlate closely with digestibility in dogs and blue foxes. ${ }^{35-37}$ In this study, we utilized mink as a model animal to evaluate the safety and assess the potential of Antarctic krill meal as a supplementary protein and lipid source in commercial pet foods. A dose-response design was used, which included levels substantially higher than applicable for commercial feeds to reveal possible challenges and thresholds related to the product.

\section{Materials and methods Experimental site and test substance}

The live animal work of the project, as well as evaluation of nutritional characteristics of the diets, was conducted at the Norwegian University of Life Sciences (NMBU), Department of Animal and Aquacultural Sciences, Ås, Norway, where feeds were also produced. The farm is under the supervision of the Norwegian Research Authority, and Norwegian protocols of ethical standards concerning experiments involving animals were followed. Evaluation of health-related effects of the diets was conducted at the NMBU School of Veterinary Medicine, Department of Basic Sciences and Aquatic Medicine, Oslo, Norway. The Antarctic krill meal used in the experiment was produced on June 1, 2010, and supplied by Aker BioMarine Antarctic AS (Oslo, Norway).

\section{Experiment I: Atlantic krill digestibility Feed composition}

In the digestibility experiment, Antarctic krill meal accounted for $100 \%$ of the protein in the diet. The chemical contents of the Antarctic krill meal and of Norse-LT 94 fishmeal (high-quality fishmeal) are compared in Table 1. The other ingredients used in the Antarctic krill meal diet were standard ingredients with negligible nitrogen content (Table 2). This allowed the determination of protein digestibility in the Antarctic krill meal as the sole source of protein. In addition, lipid and starch digestibility also were determined, but most of the lipid and starch originated from the other ingredients. Soybean oil was used as the main lipid source, accounting for $82 \%$ of the total lipid in the experimental diet. The remaining lipid originated from the Antarctic krill meal. Digestibility of lipid in soybean oil is approximately $96 \%,{ }^{38}$ a value that was used when estimating the digestibility of lipid from the Antarctic krill meal. Dietary starch originated from corn only.

\section{Animals and housing}

Four adult male mink of the black genotype ( $>6$ months) were given an Antarctic krill meal diet and housed according to Norwegian National regulations. During the experiment, the animals were kept singly in metabolic cages designed for separate collection of feces and urine. The mean body weight $(\mathrm{BW}) \pm$ standard deviation (SD) of the animals was $2.25 \pm 0.25 \mathrm{~kg}$. Daily feed allowance (136 g per day) was planned to meet the requirement for metabolizable energy (ME). The experiment lasted for 7 days, of which the first 3 days were an adaptation period. During the last 4 days, the feed intake was measured precisely and feces collected daily. Fecal consistency was evaluated using a scale 
Table I Chemical content of Antarctic krill meal compared to LT-fishmeal

\begin{tabular}{lll}
\hline Component & $\begin{array}{l}\text { Antarctic krill } \\
\text { meal } \mathbf{( g / k g )}\end{array}$ & $\begin{array}{l}\text { LT- } \\
\text { fishmeal } \mathbf{( g /} \\
\mathbf{~ k g})\end{array}$ \\
\hline Dry matter & 918 & 915 \\
Ash & 118 & 152 \\
Crude protein & 644 & 685 \\
Crude fat & 165 & 82 \\
Carbohydrates (difference) & 56 & - \\
Amino acids & & \\
Cystine & 7.0 & 6.6 \\
Methionine & 20.4 & 18.9 \\
Aspargine & 75.9 & 66.7 \\
Threonine & 28.4 & 27.8 \\
Serine & 28.7 & 29.6 \\
Glutamine & 102.0 & 100.5 \\
Proline & 22.9 & 27.0 \\
Glycine & 29.6 & 44.7 \\
Alanine & 38.4 & 43.9 \\
Valine & 36.4 & 36.1 \\
Isoleucine & 37.2 & 32.2 \\
Leucine & 54.6 & 52.0 \\
Tyrosine & 35.3 & 23.1 \\
Phenylalanine & 34.1 & 26.8 \\
Histidine & 17.3 & 16.0 \\
Lysine & 56.0 & 56.7 \\
Arginine & 43.2 & 41.8 \\
Total amino acids & 669.7 & 654.3 \\
\hline Ab & &
\end{tabular}

Abbreviation: LT, low temperature dried.

from 1 (loose, poorest) to 5 (firm, best). Feces were stored frozen pending chemical analyses. Prior to the analysis, the feces were freeze-dried, weighed, homogenized, and sieved to remove hair.

Table 2 Diet composition, chemical content, and average digestibility of crude protein, fat, and starch in the digestibility trial (Experiment I)

\begin{tabular}{ll}
\hline Ingredients $(\mathrm{g} / \mathrm{kg})$ & \\
Antarctic krill meal & 191 \\
Pregelatinized corn starch & 93 \\
Soybean oil & 93 \\
Cellulose powder & 15 \\
Vitamins/mineral mixture & 0.9 \\
Water & 608 \\
Sum & 1,000 \\
Chemical content (g/kg) & \\
Dry matter & 363 \\
Ash & 23 \\
Crude protein & 123 \\
Crude fat & 113 \\
Carbohydrates (difference) & 106 \\
Digestibility (\%) & \\
Protein & $85.1 \pm 0.6$ \\
Fat & $97.8 \pm 0.6$ \\
Starch & $98.2 \pm 0.3$ \\
\hline
\end{tabular}

Note: Digestibility data are presented as mean \pm SD.

\section{Chemical analyses}

Samples of Antarctic krill meal and feces were analyzed for dry matter (heating at $105^{\circ} \mathrm{C}$ for $16-18$ hours), ash (combustion at $550^{\circ} \mathrm{C}$ to constant weight), crude protein as nitrogen $\times 6.25$ (by the semi-micro-Kjeldahl method; Kjeltec Auto System, Tecator, Sweden), lipid (diethylether extraction in a Fosstec analyzer [Tecator] after $\mathrm{HCl}$ hydrolysis), starch (measured as glucose after hydrolysis by $\alpha$-amylase [Novo Nordisk A/S, Bagsvaerd, Denmark]), and amylo-glucosidase (Boehringer Mannheim GmbH, Mannheim, Germany), followed by glucose determination by the "Glut-DH method" (Merck, Darmstadt, Germany). Amino acid analyses of the Antarctic krill meals were performed according to Commission Directive 98/64/EC. ${ }^{39}$

\section{Digestibility calculation}

The apparent digestibility values for protein, fat, and starch were calculated from the four animals fed with Antarctic krill meal. The intakes of crude protein, lipid, and starch were calculated based on the chemical analyses of the Antarctic krill meal (Table 1) and other standard ingredients. The apparent digestibility was calculated using the following formula:

$$
\begin{aligned}
& \text { Apparent digestibility }(\%) \\
& =[(\text { nutrient consumed }- \text { nutrient excreted in feces }) \\
& \quad /(\text { nutrient consumed })] \times 100 .
\end{aligned}
$$

\section{Statistical analysis}

Differences in the initial and final BWs were examined using Student's $t$-test and were considered significant for $P<0.05$.

\section{Experiment 2: reproduction}

\section{Feed composition}

In the reproduction experiment, Antarctic krill meal inclusion was tested at four levels, including a control diet containing no Antarctic krill meal. The diets were formulated to have an ME content of $5.0 \mathrm{MJ} / \mathrm{kg}$ on a wet weight basis, and the proportions of ME from proteins, lipids, and carbohydrates were $40 \%, 45 \%$, and $15 \%$, respectively. The diets were formulated with Antarctic krill levels corresponding to contributions in dry matter of $0 \%, 9 \%, 17 \%$, and $35 \%$ (diets named K0, K9, K17, and K35, respectively), and with total protein of $0 \%, 14 \%, 27 \%$, and $57 \%$. The Antarctic krill meal protein replaced the fishmeal protein. New batches of the diets were produced once weekly. Feed for the first 3 days was kept chilled at $4^{\circ} \mathrm{C}$ until feeding, while the feed for the last 4 days was stored frozen $\left(-20^{\circ} \mathrm{C}\right)$ at the time of production and thawed the day before use. The animals were 
kept in semi-outdoor houses with natural daylight, fed once daily, and given drinking water by a semiautomatic system (nipples). Feed was provided on netting suspended from the top wire of the cage, and when the kits started to eat at three weeks of age, also on netting suspended from the top wire of the nest box. Feed was moderately restricted before mating and during gestation. After birth, feeding was not restricted, but individual feed allowance was adjusted according to the number of kits. Feed intake and ME consumption were recorded on a group basis.

\section{Animals and housing}

Standard female mink (black genotype, BWs 955-1340 g) were allocated to four groups of 16 animals each and placed on diets $\mathrm{K} 0$, K9, K17, or K35. The 117-day experimental period consisted of a premating period from February 17 until mating started on March 7 and a gestation period of approximately 50 days, followed by parturition, lactation, and early kit growth (lasting 49 days after birth). All females were mated twice. The first mating took place in the second week of March, and the second 7-9 days later. Females were not checked for successful copulation. Each female was kept in a breeding cage equipped with a nest box. The size of each cage was $0.45 \mathrm{~m}$ (height) $\times 0.27 \mathrm{~m}^{2}$ (floor area). The cages were arranged in two rows, and females belonging to the same group were placed in cages side by side, eight in each row with an empty cage between different groups. BWs of females and kits, as well as the litter size, were recorded regularly. Females that exhibited poor growth, appetite, or body condition prior to mating (as evaluated by a skilled technician) were replaced by reserve females maintained on the same diet. No replacements were made after mating. Maternal animals were removed from the study if they were barren or were found to have produced only stillborn kits. After weaning, some of the kits were either placed in the same experimental groups as their mothers for use in a subsequent study or were taken out of the experiment and given a commercial feed until pelting.

\section{Sampling}

The kits were weaned at 49 days of age. After weaning, the mothers were euthanized, necropsied, and sampled for additional analyses. Maternal animals were rendered unconscious by electric shock using a Euthantos 2 (Lima A/S, Sandnes, Norway) designed for this purpose. Animals were then immediately euthanized by cervical dislocation. Blood samples were taken after euthanasia by cardiac puncture. The animals were dissected, and the organs examined grossly, and weighed.
Tissue samples for histology were taken from the stomach, kidney, spleen, adrenal glands, and heart of $\mathrm{K} 0$ and $\mathrm{K} 35$ animals, and from the liver, jejunum, colon, and rectum of all animals, fixed in neutral buffered formalin (4\% formaldehyde; $\mathrm{pH} 7.4$ ), and processed using routine methods (NMBU School of Veterinary Medicine). Tissue sections were stained with hematoxylin and eosin and evaluated blindly under a light microscope in randomized order.

\section{Chemical, blood, and microbiological analyses}

Methods used for chemical analyses were identical to those used in the digestibility experiment. In addition, Antarctic krill meal, Norse-LT 94 fishmeal, and the diets were analyzed for copper, arsenic, calcium, and fluoride. The latter analyses were conducted at Eurofins' laboratory, Kambo, Norway, using standard procedures at this laboratory. ${ }^{40,41}$ Blood and plasma samples were analyzed at the Central Laboratory of the NMBU School of Veterinary Medicine for complete blood cell counts and plasma biochemistry profiles employing certified assays. Standard methods were used to measure the hygiene quality and $\mathrm{pH}$ of the diets, and a modified Conway method was used to determine total volatile nitrogen (TVN) at the laboratory of the Norwegian Fur Breeders' Association, Oslo, Norway. ${ }^{42}$ The hygiene quality parameters used were total bacterial, fecal coliform, and fungal counts.

\section{Statistics}

The means and SDs were calculated for all quantitative data. Data within groups were evaluated for homogeneity of variance and normality by Bartlett's test. Where Bartlett's test indicated homogeneous variances, treated and control groups were compared using a one-way analysis of variance (ANOVA). When the ANOVA was significant, a Tukey's test for multiple comparisons was performed to compare the results of all groups. When the variances were significantly different by Bartlett's test, groups were compared using a nonparametric method (Kruskal-Wallis nonparametric ANOVA). When the nonparametric ANOVA was significant, all groups were compared using Dunn's test (Prism 5.02; GraphPad Software, San Diego, CA, USA). The critical value for significance of all comparisons was $P<0.05$.

\section{Results}

\section{Experiment I: digestibility}

The compositional data for the Antarctic krill meal, Norse-LT 94 fishmeal, and the diet used in the digestibility experiment are given in Tables 1 and 2, respectively. There was high similarity in the chemical composition and amino 
acid composition between the Antarctic krill meal and the Norse-LT 94 fishmeal (Table 1). Dry matter in the krill meal diet was approximately $36 \%$, while crude protein and fat were $12 \%$ and $11 \%$, respectively (Table 2 ). The carbohydrate component accounted for approximately $11 \%$ of the diet. Mink fed with the Antarctic krill diets consumed close to $100 \%$ of the feed offered, showing good palatability of the diets. BWs were slightly but not significantly reduced for all four animals during the 7-day experimental period $(2,339 \pm 247 \mathrm{~g}$ prior to feeding vs $2,218 \pm 254 \mathrm{~g}$ after feeding, $P>0.05$ ), showing that the dietary restriction to $136 \mathrm{~g}$ feed per day did not completely cover the ME requirement. There was no sign of diarrhea, and mean fecal consistency scores during the 4-day collection were within normal limits (data not shown). Average protein, lipid, and starch digestibility of the Antarctic krill meal were $85.1 \%, 97.8 \%$, and 98.2\%, respectively (Table 2).

\section{Experiment 2: reproduction}

Diet characteristics

Compositions of the four test diets (krill meal at $0 \%, 9 \%$, $17 \%$, and $35 \%$ of dry matter) are provided in Table 3 . In the presentation of results, they are labeled according to the krill meal's contribution to dry matter as follows: K0, K9, K17, and K35. Proximate analysis of the samples showed that nutrient and calculated $\mathrm{ME}$ requirement content were quite similar for the four diets (Table 4). During the experiment, it became clear that the consistency of the K35 diet was poorer than that of the others. It tended to dry out more quickly and crumble, increasing the feed spillage from the cage top net wire more than other dose levels. Increasing the water content

Table 3 Composition of diets used in the reproduction trial (Experiment 2)

\begin{tabular}{lllll}
\hline Ingredients (g/kg) & K0 & K9 & K I7 & K35 \\
\hline Antarctic krill meal & - & 35.5 & 69.5 & 136 \\
Fishmeal (LT-fishmeal) & 156 & 120.5 & 83 & 13 \\
Precooked carbohydrates & 142 & 142 & 140 & 132 \\
Cod scraps & 142 & 142 & 139 & 131 \\
Poultry by-products & 142 & 142 & 139 & 131 \\
Lard (pig fat) & 14.2 & 14.2 & 14.0 & 13.0 \\
Soybean oil & 14.2 & 14.2 & 14.0 & 13.0 \\
Vitamin/mineral mixture & 2 & 2 & 2 & 2 \\
Water & 388 & 388 & 400 & 430 \\
Sum & 1,000 & 1,000 & 1,000 & 1,000 \\
\hline
\end{tabular}

Notes: aContent per kg: vitamin A, 2,000,000 IU; vitamin D3, 200,000 IU; vitamin E, $50,000 \mathrm{mg}$; vitamin $\mathrm{Bl}$, 15,000 mg; vitamin B2, 3,000 mg; vitamin B6, 3,000 mg; vitamin BI2, $19.5 \mathrm{mg}$; Ca (-D-pantothenic acid), 3,332 mg; niacin, 5,005 mg; biotin, $30 \mathrm{mg}$; folic acid, $301 \mathrm{mg}$; ferrous sulfate, $610 \mathrm{mg}$; ferrous fumarate, $15,280 \mathrm{mg}$; Fe-chelated, 4,II0 mg; copper sulfate, I,250 mg; manganese oxide, 7,502 mg; zinc oxide, $9,998 \mathrm{mg}$; Ca iodinate, $63.5 \mathrm{mg}$; Na selenite, $99.9 \mathrm{mg}$; cobalt carbonate, $60 \mathrm{mg}$. Abbreviation: LT, low temperature dried.
Table 4 Chemical content, energy, TVN, and $\mathrm{pH}$ of diets in the reproduction trial (Experiment 2)

\begin{tabular}{|c|c|c|c|c|}
\hline Parameter & KO & K9 & $\mathbf{K I 7}$ & $\mathbf{K 3 5}$ \\
\hline \multicolumn{5}{|l|}{$\mathrm{g} / \mathrm{kg}$ diet } \\
\hline DM & 380 & 379 & 372 & 350 \\
\hline Ash & 42 & 40 & 39 & 34 \\
\hline Crude protein & 168 & 168 & 166 & 154 \\
\hline Crude fat & 67 & 70 & 70 & 65 \\
\hline Carbohydrates & 103 & 101 & 98 & 97 \\
\hline \multicolumn{5}{|l|}{ g/kg DM } \\
\hline Ash & 111 & 106 & 105 & 97 \\
\hline Crude protein & 442 & 443 & 446 & 440 \\
\hline Crude fat & 176 & 185 & 188 & 185 \\
\hline Carbohydrates & $27 \mid$ & 266 & 261 & 278 \\
\hline $\mathrm{pH}$ & 6.47 & 6.75 & 6.79 & 7.30 \\
\hline TVN (\%) & 1.0 & 0.9 & 0.6 & 0.5 \\
\hline \multicolumn{5}{|l|}{ Energy estimates } \\
\hline$M E^{a} \mathrm{MJ} / \mathrm{kg}$ & 6.17 & 6.24 & 6.19 & 5.80 \\
\hline MJ ME/kg DM & 16.24 & 16.46 & 16.64 & 16.57 \\
\hline $\begin{array}{l}\text { ME proportion from } \\
\text { protein/fat/ } \\
\text { carbohydrates (\%) }\end{array}$ & $42 / 39 / 19$ & $4 I / 40 / 19$ & $4 I / 4 I / I 8$ & $4 I / 39 / 20$ \\
\hline
\end{tabular}

Notes: Results are mean values for three samples. Carbohydrate was determined by difference calculation (carbohydrates $=$ dry matter $-($ protein + fat + ash $)$ ). aME content was determined by use of standard digestibility factors given by the Norwegian Fur Breeders' Association of $82 \%, 90 \%$, and $68 \%$ for protein, fat, and carbohydrates, respectively, and ME content of $18.8 \mathrm{~kJ} / \mathrm{g}, 39.8 \mathrm{~kJ} / \mathrm{g}$, and $17.6 \mathrm{~kJ} / \mathrm{g}$ digestible protein, fat, and carbohydrates, respectively. Data from Hansen et al..$^{57}$

Abbreviations: TVN, total volatile nitrogen; DM, dry matter; ME, metabolizable energy; MJ, megajoules.

in the diet reduced the problem. Total volatile nitrogen (TVN) was low for all diets and decreased with increasing inclusion of Antarctic krill meal, indicating that TVN was lower in the Antarctic krill meal than in the fishmeal (Table 4). The $\mathrm{pH}$ of the diets tended to increase with increasing content of Antarctic krill meal (Table 4). The reason for this is not clear, but the increase in $\mathrm{pH}$ was not considered of importance and did not affect palatability of the diets.

Dietary concentrations of copper, fluoride, arsenic, and calcium are presented in Table 5. Concentrations of copper and fluoride were higher in the Antarctic krill meal than in the fishmeal, while the opposite was observed for arsenic. For calcium, the level was similar in Antarctic krill meal and the fishmeal. In the diets, the element levels reflected to a large extent the inclusion level of Antarctic krill meal and fishmeal (Table 5). Diet K35 had three times the copper level and four times the fluoride level compared to K0. It should be noted that $2.5 \mathrm{mg} / \mathrm{kg} \mathrm{CuSO}$, was added to all diets (as a component of the mineral supplement). Thus, a much larger proportion of copper originated from the supplement in the $\mathrm{K} 0$ diet than in the K35 diet. Arsenic content, which was lower in Antarctic krill meal than in fishmeal, was approximately three times 
Table 5 Mineral content of Antarctic krill meal, fishmeal, and experimental diets (Experiment 2)

\begin{tabular}{rllllll}
\hline Mineral & $\begin{array}{l}\text { Antarctic } \\
\text { krill meal }\end{array}$ & Fishmeal & K0 & K9 & K I7 & K35 \\
\hline mg/kg diet & & & & & & \\
Copper & 56 & 3.3 & 3.7 & 5.3 & 6.9 & 10.1 \\
Fluoride & 1,840 & 112 & 44 & 91 & 115 & 200 \\
Arsenic & 2.5 & 5.7 & 2.5 & 2.0 & 1.7 & 0.7 \\
Calcium & 25,000 & 26,000 & 10,750 & 10,150 & 10,590 & 8,070 \\
mg/kg DM & & & & & & \\
Copper & 61 & 3.6 & 10.0 & 14.6 & 19.8 & 30.2 \\
Fluoride & 2,004 & 122 & 119 & 251 & 328 & 594 \\
Arsenic & 2.7 & 6.2 & 6.8 & 5.6 & 4.8 & 2.2 \\
Calcium & 27,230 & 28,410 & 29,170 & 28,130 & 30,210 & 23,960 \\
\hline
\end{tabular}

Abbreviation: DM, dry matter.

higher in the $\mathrm{K} 0$ diet than in the $\mathrm{K} 35$ diet. Calcium in the $\mathrm{K} 35$ diet was approximately $18 \%$ lower than in the $\mathrm{K} 0$ diet, which corresponds to the lower ash content (Table 5). Palatability was satisfactory and feed consumption was normal for all the diets. Average feed consumption per mated female with kits, determined as grams per day or on energy (ME) basis, was similar among groups (Table 6). Fecal consistency was similar and good for all animals.

\section{Reproduction and growth responses}

All females were mated twice as planned. Four animals in the $\mathrm{K} 0$ group, two in the K17 group, and three in the K35 group did not produce offspring (Table 7). The overall percentage of barren females for the study ( $9 / 64$ or $14 \%)$ was slightly higher than usual $(10 \%-11 \%) .{ }^{43}$ The relatively high percentage of barren females in the control group (25\%) was due to the mating of two of the females with the same male which was likely sterile because none of his matings (including another in the K17 group) produced offspring. Shortly after the beginning of the experiment, one female in the K35 group died. Necropsy revealed hemorrhagic ulceration of the gastric tissue. The animal was replaced. One animal in the K17 group died of an undetermined cause shortly before the scheduled termination. The last recorded BW of the animal

Table 6 Average feed consumption during the experimental period (Experiment 2)

\begin{tabular}{lllll}
\hline Feed consumption $^{\mathbf{a}}$ & K0 & K9 & K 17 & K35 \\
\hline g/mated female/day & 235 & 233 & 233 & 237 \\
MJ/mated female/day & 1.45 & 1.45 & 1.44 & 1.37 \\
g/born litter/day & 298 & 233 & 266 & 292 \\
MJ/born litter/day & 1.83 & 1.45 & 1.65 & 1.69 \\
\hline
\end{tabular}

Note: ${ }^{A}$ As feed intake was recorded for each treatment as a whole and the animals ate the feed that was given, no statistical parameters were calculated.

Abbreviation: MJ, megajoules
Table 7 Reproductive success, litter size, and kit survival of mink fed the experimental diets (Experiment 2)

\begin{tabular}{lllll}
\hline & K0 & K9 & K17 & K35 \\
\hline $\begin{array}{l}\text { Females mated, number } \\
\text { Litters born, number }\end{array}$ & 16 & 16 & 16 & 16 \\
$\begin{array}{l}\text { Litter size (mean } \pm \text { SD) } \\
\text { 2 days post-parturition }\end{array}$ & $5.8 \pm 1.4$ & $5.3 \pm 1.9$ & $5.0 \pm 1.9$ & $6.3 \pm 2.3$ \\
7 days post-parturition & $5.6 \pm 1.6$ & $5.0 \pm 2.2$ & $4.4 \pm 1.9$ & $5.8 \pm 2.8$ \\
21 days post-parturition & $5.6 \pm 1.6$ & $5.0 \pm 2.2$ & $4.4 \pm 1.9$ & $5.5 \pm 2.8$ \\
$\begin{array}{l}\text { 49 days post-parturition } \\
\text { (weaning) }\end{array}$ & $5.5 \pm 1.5$ & $4.9 \pm 2.1$ & $4.3 \pm 1.8$ & $5.1 \pm 2.8$ \\
$\quad$ Survival until weaning (\%) & 95.7 & 93.8 & 88.6 & 92.7 \\
\hline
\end{tabular}

Note: a One litter with one kit was stillborn.

Abbreviation: SD, standard deviation.

(490 g) was considerably lower than its weight at postpartum day $21(1160 \mathrm{~g})$, suggesting that the animal may have died due to lack of sufficient feed intake to maintain health while nursing its litter of five.

Krill inclusion level did not affect litter size significantly (Table 7). A total of 302 kits were born in 55 litters. A singleton kit from a female in the $\mathrm{K} 9$ group was stillborn. No other kits were stillborn. One female each from the K9 and K35 groups delivered live singleton litters, which survived to day 7 only. Kits that survived to day 7 generally survived to study termination, regardless of the treatment. The overall survival rate to weaning was $92.7 \%$, and ranged from $88.6 \%$ in the $\mathrm{K} 17$ group to $95.7 \%$ in the $\mathrm{K} 0$ group. The average BW of the females showed only minor differences among treatments (Table 8). BWs of the kits in the K35 group were significantly lower than those of the K0 group at 49 days post-partum (Table 8). As the litter size usually correlates negatively with weights of the kits, it should be noted that the highest initial mean litter size and lowest BW at weaning were observed for the K35 treatment.

\section{Maternal effects}

In maternal animals, relative organ weights for stomach, intestine, liver, and spleen showed significant relationships with dietary krill meal levels (Table 9). Relative stomach, intestine, and spleen weights were similar among K0, K9, and $\mathrm{K} 17$ groups but higher in the $\mathrm{K} 35$ group $(P<0.05)$. The relative liver weights were not dose-dependent; only the weights for the K17 and K35 groups were significantly different from each other $(P<0.05)$.

Hematological evaluations were unremarkable, with the exception of an increased platelet count in the K35 group compared to the $\mathrm{K} 0$ group $(P<0.05)$ (Table 10). Although there was a tendency toward decreased red blood cell count (RBC) and hemoglobin (HGB) concentration and an 
Table 8 Body weights of females and kits from the start of reproduction trial until weaning (Experiment 2)

\begin{tabular}{|c|c|c|c|c|c|}
\hline \multirow[t]{2}{*}{ Body weight (g) } & \multicolumn{4}{|l|}{ Diet } & \multirow[t]{2}{*}{$P$-value } \\
\hline & KO & K9 & KI7 & K35 & \\
\hline \multicolumn{6}{|l|}{ Females } \\
\hline BW February 17 & $1,156 \pm 106$ & $I, I 5 I \pm I I 0$ & $1,130 \pm 85$ & $\mathrm{I}, 033 \pm 4 \mathrm{I} 3$ & 0.511 \\
\hline BW March 4 & $|, 098 \pm| 2 \mid$ & $\mathrm{I}, 030 \pm \mathrm{I} \mathrm{I}$ & $1,000 \pm 84$ & $1,106 \pm 112$ & 0.052 \\
\hline BW 21 days post-parturition & $1,261 \pm 163$ & $1,309 \pm 163$ & $1,282 \pm 125$ & $1,234 \pm 184$ & 0.675 \\
\hline BW 49 days post-parturition & $1,114 \pm 135$ & $1,099 \pm 173$ & $|| ,3| \pm| 6 \mid$ & $1,046 \pm 153$ & 0.554 \\
\hline \multicolumn{6}{|l|}{ Kits } \\
\hline BW 2 I days post-parturition & $157 \pm 13^{a, b}$ & $158 \pm \mid 7^{\mathrm{a}, \mathrm{b}}$ & $163 \pm 25^{a}$ & $14 \mid \pm 19^{b}$ & 0.032 \\
\hline BW 49d post-parturition & $505 \pm 6 \mathrm{I}^{\mathrm{a}}$ & $476 \pm 65^{\mathrm{a}, \mathrm{b}}$ & $535 \pm 78^{a}$ & $407 \pm 79^{b}$ & 0.0005 \\
\hline
\end{tabular}

Notes: Values are presented as mean \pm standard deviation. Data were analyzed using analysis of variance. Values with different superscripts are significantly different from each other $(P<0.05)$.

Abbreviation: BW, body weight.

increased red blood cell distribution width (RDW) in the K35 group compared to the $\mathrm{K} 0$ group, the values did not reach statistical significance $(P>0.05)$. The mean white blood cell count (WBC) was higher in K35 animals compared to K0 animals; however, the values did not reach statistical significance $(P=0.0702)$ (Table 11). The difference in total WBC counts was largely attributable to increased neutrophil numbers (Table 11). Monocytes were significantly increased in the $\mathrm{K} 35$ group compared to the $\mathrm{K} 0$ group $(P<0.05)$, but they constituted a much smaller percentage of the total WBC count (Table 11). The increases in WBC counts in the K35 group were largely attributed to three animals that exhibited markedly increased total WBC $\left(20.2-20.5 \times 10^{9} / \mathrm{L}\right)$, neutrophil $\left(14.6-17.9 \times 10^{9} / \mathrm{L}\right)$, and monocyte counts $\left(0.8-1.0 \times 10^{9} / \mathrm{L}\right)$.

A few significant relationships were found for the blood biochemistry variables and the dietary krill meal level (Table 12). The liver enzymes (aspartate transaminase and alanine transaminase) and creatine kinase showed large individual variation, most notably in the K35 group, in which several high values were observed. No significant differences were detected between groups for these parameters. A significant increase in amylase occurred in the $\mathrm{K} 35$ group compared to the $\mathrm{K} 0$ group $(P<0.05)$. The total plasma protein was not significantly related to dietary krill meal level, but albumin was lower in the $\mathrm{K} 35$ group $(P<0.05)$. Consequently, globulin (a calculated value) was higher in this group $(P<0.05)$. It should be noted, however, that the analyses were performed on blood plasma, and therefore the "globulin" value represents not only globulins but clotting factors as well. Free fatty acids tended to be higher in all krill meal groups compared to the $\mathrm{K} 0$ group, but did not increase in a dose-dependent manner.

Generally, the gross anatomical appearance of the organs and histomorphology of tissues were normal. The pathological changes that were observed were generally unrelated to the dietary krill level, with the exception of increased numbers of animals with intestinal redness in all krill meal groups (Table 13). Focal leukocyte infiltration was commonly observed within the glandular region of stomach samples, with no difference in prevalence of these types of lesions between the K0 and K35 groups.

Table 9 Relative organ to body weights (g/l00 g BW) of females after weaning of kits (Experiment 2)

\begin{tabular}{|c|c|c|c|c|c|}
\hline \multirow[t]{2}{*}{ Organ } & \multicolumn{4}{|l|}{ Diet } & \multirow[t]{2}{*}{$P$-value } \\
\hline & $\mathbf{K O}$ & K9 & KI 7 & K35 & \\
\hline Stomach & $0.64 \pm 0.1 \mathrm{I}^{\mathrm{a}}$ & $0.62 \pm 0.07^{\mathrm{a}}$ & $0.62 \pm 0.12^{\mathrm{a}}$ & $0.84 \pm 0.14^{b}$ & $<0.0001$ \\
\hline Intestine* & $3.01 \pm 0.67^{a}$ & $2.86 \pm 0.60^{\mathrm{a}}$ & $2.88 \pm 0.68^{a}$ & $3.86 \pm 0.84^{\mathrm{b}}$ & 0.001 \\
\hline Rectum & $0.27 \pm 0.05$ & $0.27 \pm 0.05$ & $0.27 \pm 0.06$ & $0.32 \pm 0.06$ & 0.066 \\
\hline Liver & $2.95 \pm 0.62^{\mathrm{a}, \mathrm{b}}$ & $2.64 \pm 0.47^{\mathrm{a}, \mathrm{b}}$ & $2.33 \pm 0.87^{a}$ & $3.06 \pm 0.43^{b}$ & 0.020 \\
\hline Kidney**,*** & $0.62 \pm 0.10$ & $0.61 \pm 0.05$ & $0.59 \pm 0.10$ & $0.67 \pm 0.12$ & 0.299 \\
\hline Spleen*** & $0.26 \pm 0.09^{a}$ & $0.23 \pm 0.09^{a}$ & $0.89 \pm 2.40^{\mathrm{a}}$ & $0.38 \pm 0.1 I^{b}$ & 0.004 \\
\hline Heart & $0.76 \pm 0.12$ & $0.80 \pm 0.14$ & $0.72 \pm 0.07$ & $0.76 \pm 0.16$ & 0.387 \\
\hline Brain & $0.73 \pm 0.07$ & $0.77 \pm 0.11$ & $0.75 \pm 0.11$ & $0.82 \pm 0.11$ & 0.136 \\
\hline Adrenals & $0.010 \pm 0.000$ & $0.009 \pm 0.004$ & $0.009 \pm 0.003$ & $0.010 \pm 0.000$ & 0.371 \\
\hline Gonads & $0.030 \pm 0.007$ & $0.030 \pm 0.009$ & $0.028 \pm 0.007$ & $0.031 \pm 0.009$ & 0.907 \\
\hline
\end{tabular}

Notes: Values are presented as mean \pm standard deviation. Data were analyzed using analysis of variance unless stated otherwise. Values with different superscripts are significantly different from each other $(P<0.05)$. *Includes duodenum, jejunum, ileum, and colon; **includes both kidneys; ***data were analyzed using a Kruskal-Wallis test $(P<0.05)$. 
Table 10 Red blood cell variables of females after weaning in the reproduction trial (Experiment 2)

\begin{tabular}{|c|c|c|c|c|c|}
\hline \multirow[t]{2}{*}{ Parameter } & \multicolumn{4}{|l|}{ Diet } & \multirow[t]{2}{*}{$P$-value } \\
\hline & KO & K9 & KI7 & K35 & \\
\hline $\mathrm{RBC}\left(\times 10^{12} / \mathrm{L}\right)$ & $9.37 \pm 0.88$ & $9.88 \pm 1.04$ & $9.59 \pm 1.02$ & $8.78 \pm 1.08$ & 0.061 \\
\hline HGB $(g / L)$ & $182 \pm 17$ & $186 \pm 18$ & $179 \pm 27$ & $167 \pm 24$ & 0.183 \\
\hline HCT (L/L) & $0.59 \pm 0.06$ & $0.61 \pm 0.06$ & $0.59 \pm 0.08$ & $0.56 \pm 0.08$ & 0.328 \\
\hline $\mathrm{MCV}(\mathrm{fL})$ & $63.1 \pm 2.6$ & $62.1 \pm 2.7$ & $61.6 \pm 4.7$ & $64 \pm 3.6$ & 0.380 \\
\hline $\mathrm{MCHC}(\mathrm{g} / \mathrm{L})$ & $309 \pm 14$ & $304 \pm 9$ & $302 \pm 13$ & $298 \pm 8$ & 0.120 \\
\hline RDW (\%) & $13.0 \pm 0.5$ & $12.9 \pm 0.7$ & $14.0 \pm 2.5$ & $14.1 \pm 1.8$ & 0.086 \\
\hline PLT $\left(\times 10^{9} / L\right)$ & $656 \pm 103^{a}$ & $720 \pm 150^{a, b}$ & $704 \pm 190^{\mathrm{a}, \mathrm{b}}$ & $862 \pm 232^{b}$ & 0.046 \\
\hline
\end{tabular}

Notes: Values are presented as mean \pm standard deviation. Data were analyzed using analysis of variance. Values with different superscripts (letters) are significantly different from each other.

Abbreviations: HCT, hematocrit; HGB, hemoglobin; MCHC, mean cell hemoglobin concentration; MCV, mean cell volume; PLT, platelet count; RBC, red blood cells; RDW, red blood cell distribution width.

Polymorphonuclear leukocyte infiltration of the lamina propria and epithelium of the rectum was observed in four individuals from the K35 group (Figure 1), three of which also exhibited areas of apparent hyperemia in the rectal epithelium. Two of these individuals also displayed elevated blood WBC counts (11.6-20.3×10\%/L) compared to normal $\left(8.0 \times 10^{9} / \mathrm{L}\right.$, as determined by Mustonen $\left.{ }^{44}\right)$. The histomorphological appearance of sections of rectum from animals in the K9 and K17 groups was normal. The histology of the jejunum or colon was not affected by inclusion of krill meal.

The histological examination revealed a significantly smaller size of glycogen vacuoles in the livers of the K35 group animals compared to K0 group of animals (Figure 2). Single focal leukocyte aggregations were observed in the livers of K0 (2/12), K9 (4/16), K17 (1/13), and K35 (0/13) animals. A few more animals in the K17 and K35 groups exhibited small, multifocal $(\leq 5)$ inflammatory foci in the liver compared to the $\mathrm{K} 0$ and $\mathrm{K} 9$ groups, namely $\mathrm{K} 0(0 / 12)$, K9 (1/16), K17 (3/13), and K35 (4/13). An example of a single focal aggregation from an animal in the $\mathrm{K} 0$ group and a multifocal leukocyte aggregation from an animal in the K35 group is shown in Figure 3. Most kidney samples appeared histologically normal. Abnormalities were noted in 3/12 samples from the K0 group, and 4/13 samples from the K35 group. Abnormalities in both groups included the presence of basophilic crystalline material within renal tubules, accompanied by tubular degeneration (Figure 4), which was sometimes (but not always) accompanied by signs of inflammation. One individual from the K35 group, in which a kidney stone was found on necropsy, had marked multifocal to diffuse inflammation, degenerative tubular epithelium, and a dilated renal pelvis.

Overall, spleen samples appeared normal, with the exception of pigment deposition in a greater number of animals in the K35 group than the $\mathrm{K} 0$ group (5 vs 1 ). A few animals from both groups had active lymphoid follicles, which did not correlate with peripheral blood lymphocyte counts. Several samples from both the K0 and K35 groups (9/12 samples in the $\mathrm{K} 0$ group and 7/13 samples in the K35 group) showed areas of cellular vacuolar degeneration, which was sometimes, but not always, accompanied by signs of necrosis and mild inflammation in the adrenal cortex. Heart tissue appeared normal in both the $\mathrm{K} 0$ and $\mathrm{K} 35$ groups.

Table I I WBC $\left(\times 10^{9} / \mathrm{L}\right)$ of females after weaning of kits in the reproduction trial (Experiment 2)

\begin{tabular}{llllll}
\hline Parameter & Diet & & & K35 \\
\cline { 2 - 5 } & Ko & K9 & KI7 & P-value \\
\hline Total WBC & $4.40 \pm 2.30$ & $5.89 \pm 3.92$ & $5.15 \pm 2.93$ & $10.95 \pm 6.98$ \\
Neutrophils & $2.90 \pm 1.39$ & $4.03 \pm 3.49$ & $3.34 \pm 1.90$ & $8.13 \pm 5.92$ & 0.070 \\
Lymphocytes & $1.04 \pm 0.91$ & $1.38 \pm 1.08$ & $1.32 \pm 1.22$ & $2.04 \pm 1.88$ & 0.150 \\
Monocytes & $0.25 \pm 0.10^{\mathrm{a}}$ & $0.38 \pm 0.25^{\mathrm{a}, \mathrm{b}}$ & $0.34 \pm 0.20^{\mathrm{a}, \mathrm{b}}$ & $0.58 \pm 0.3 \mathrm{I}^{\mathrm{b}}$ & 0.027 \\
Eosinophils & $0.15 \pm 0.13$ & $0.11 \pm 0.06$ & $0.10 \pm 0.06$ & $0.11 \pm 0.05$ & 0.638 \\
Basophils & $0.02 \pm 0.04$ & $0.03 \pm 0.05$ & $0.08 \pm 0.10$ & $0.09 \pm 0.11$ & 0.127 \\
\hline
\end{tabular}

Notes: Values are presented as mean \pm standard deviation. All data were analyzed using a Kruskal-Wallis test except data for lymphocytes, which were analyzed by ANOVA. Values with different superscripts are significantly different from each other $(P<0.05)$.

Abbreviations: WBC, white blood cell count; ANOVA, analysis of variance. 
Table I 2 Blood biochemistry profile of females after weaning of kits in the reproduction trial (Experiment 2)

\begin{tabular}{|c|c|c|c|c|c|}
\hline \multirow[t]{2}{*}{ Parameter } & \multicolumn{4}{|l|}{ Diet } & \multirow[t]{2}{*}{$P$-value } \\
\hline & KO & K9 & $K 17$ & K35 & \\
\hline AST $(\mathrm{U} / \mathrm{L})^{*}$ & $164 \pm 74$ & $184 \pm 108$ & $179 \pm 120$ & $639 \pm 1,354$ & 0.997 \\
\hline $\operatorname{ALT}(\mathrm{U} / \mathrm{L})^{*}$ & $149 \pm 49$ & $222 \pm 142$ & $149 \pm 57$ & $543 \pm 1,394$ & 0.366 \\
\hline $\mathrm{AP}(\mathrm{U} / \mathrm{L})$ & $105 \pm 22$ & $107 \pm 29$ & $130 \pm 40$ & $111 \pm 23$ & 0.134 \\
\hline CK $(\mathrm{U} / \mathrm{L})^{*}$ & $926 \pm 670$ & $587 \pm 422$ & $I,|2| \pm 1,334$ & $1,664 \pm 2,600$ & 0.290 \\
\hline Amylase (U/L) & $106 \pm 13^{a}$ & $112 \pm 26^{a}$ & $111 \pm 26^{a}$ & $|4| \pm 33^{b}$ & 0.004 \\
\hline Lipase (U/L) & $34.0 \pm 3.4$ & $34.3 \pm 5.8$ & $34.4 \pm 4.2$ & $38.3 \pm 5.6$ & 0.093 \\
\hline Total protein $(g / L)$ & $71.2 \pm 4.8$ & $73.7 \pm 5.6$ & $72.7 \pm 5.5$ & $73.8 \pm 7.7$ & 0.673 \\
\hline Albumin $(g / L)$ & $40.4 \pm 3.8^{\mathrm{a}}$ & $40.3 \pm 3.2^{\mathrm{a}}$ & $39.8 \pm 3.8^{\mathrm{a}}$ & $34.8 \pm 6.1^{\mathrm{b}}$ & 0.004 \\
\hline Globulin (g/L)* & $30.8 \pm 3.0^{\mathrm{a}}$ & $33.4 \pm 4.8^{\mathrm{a}, \mathrm{b}}$ & $32.8 \pm 4.7^{\mathrm{a}, \mathrm{b}}$ & $39.0 \pm 8.0^{\mathrm{b}}$ & 0.020 \\
\hline Urea $(\mathrm{mmol} / \mathrm{L})^{*}$ & $10.0 \pm 1.6$ & $8.4 \pm 2.6$ & $10.6 \pm 6.5$ & $11.0 \pm 3.3$ & 0.088 \\
\hline Creatinine $(\mu \mathrm{mol} / \mathrm{L})^{*}$ & $94.8 \pm 17.4$ & $77.2 \pm 11.8$ & $79.2 \pm 14.1$ & $75.5 \pm 6.6$ & 0.011 \\
\hline Bile acids $(\mu \mathrm{mol} / \mathrm{L})^{*}$ & $5.75 \pm 2.99$ & $5.14 \pm 4.22$ & $5.85 \pm 2.97$ & $8.38 \pm 9.20$ & 0.634 \\
\hline Total bilirubin $(\mu \mathrm{mol} / \mathrm{L})$ & $0.50 \pm 0.52$ & $0.64 \pm 0.63$ & $0.54 \pm 0.88$ & $0.38 \pm 0.5 \mathrm{I}$ & 0.784 \\
\hline Cholesterol (mmol/L) & $9.78 \pm 1.23$ & $8.93 \pm 1.24$ & $8.7 I \pm I .07$ & $8.59 \pm 2.13$ & 0.199 \\
\hline Triglycerides (mmol/L) & $1.53 \pm 0.39$ & $1.27 \pm 0.34$ & $1.55 \pm 0.35$ & $1.52 \pm 0.40$ & 0.179 \\
\hline Free fatty acids (mmol/L)* & $0.18 \pm 0.06^{a}$ & $0.29 \pm 0.10^{\mathrm{b}}$ & $0.34 \pm 0.16^{b}$ & $0.26 \pm 0.13^{\mathrm{a}, \mathrm{b}}$ & 0.006 \\
\hline Glucose (mmol/L)* & $8.65 \pm 3.28$ & $7.74 \pm 2.26$ & $7.25 \pm 1.78$ & $8.30 \pm 4.82$ & 0.772 \\
\hline Inorganic $\mathrm{P}$ (mmol/L) & $2.15 \pm 0.50$ & $2.18 \pm 0.49$ & $2.34 \pm 0.51$ & $2.18 \pm 0.54$ & 0.781 \\
\hline $\mathrm{Ca}(\mathrm{mmol} / \mathrm{L})$ & $2.60 \pm 0.21$ & $2.61 \pm 0.12$ & $2.62 \pm 0.12$ & $2.67 \pm 0.21$ & 0.816 \\
\hline $\mathrm{Na}(\mathrm{mmol} / \mathrm{L})$ & $159 \pm 5$ & $157 \pm 5$ & $155 \pm 5$ & $156 \pm 4$ & 0.165 \\
\hline $\mathrm{K}(\mathrm{mmol} / \mathrm{L})$ & $7.66 \pm 1.45$ & $7.31 \pm 1.39$ & $7.40 \pm 1.60$ & $7.29 \pm 1.39$ & 0.923 \\
\hline $\mathrm{Cl}(\mathrm{mmol} / \mathrm{L})$ & $117 \pm 3$ & $117 \pm 3$ & $115 \pm 4$ & $117 \pm 2$ & 0.371 \\
\hline
\end{tabular}

Notes: Values are presented as mean \pm standard deviation. *Data were analyzed using a Kruskal-Wallis test. All other data were analyzed by ANOVA. Values with different superscripts (letters) are significantly different from each other $(P<0.05)$.

Abbreviations: ALT, alanine aminotransferase; AP, alkaline phosphatase; AST, aspartate aminotransferase; Ca, calcium; CK, creatine kinase; Cl, chlorine; K, potassium; $\mathrm{Na}$, sodium; P, phosphorus.

\section{Discussion}

There is a need for new, healthy sources of protein for animals. Current sources of protein for pet food include those based on corn-gluten and soy, fish, chicken, lamb, and beef. On a BW basis, krill has the greatest amount of protein among all species, with over $60 \%$ of dry matter

Table I3 Summary of lesions observed during necropsy of females at weaning of kits (49 days post-parturition)

\begin{tabular}{lllll}
\hline Finding & Diet & & & \\
\cline { 2 - 5 } & K0 & K9 & K I7 & K35 \\
\hline Intestinal/rectal redness & 0 & 3 & 3 & 8 \\
Spleen pigmentation & 0 & $\mathrm{I}$ & 3 & 4 \\
Splenomegaly & 0 & 0 & $\mathrm{I}$ & 0 \\
Rectal mass & 0 & 0 & $\mathrm{I}$ & 0 \\
Enlarged lymph nodes & 0 & 0 & $\mathrm{I}$ & $\mathrm{I}$ \\
Kidney fibrosis & $\mathrm{I}$ & $\mathrm{I}$ & 0 & 0 \\
Kidney nodule & 0 & $\mathrm{I}$ & 0 & 0 \\
Kidney/bladder stones & 0 & 0 & 0 & $\mathrm{I}$ \\
Unilateral renal atrophy & 0 & 0 & 0 & $\mathrm{I}$ \\
Ovarian cysts & $\mathrm{I}$ & $\mathrm{I}$ & 0 & 0 \\
Ovarian blood clot & 0 & 0 & 0 & $\mathrm{I}$ \\
Ectopic pregnancy & 0 & 0 & 0 & $\mathrm{I}$ \\
Joint/bone deformities & $\mathrm{I}$ & $\mathrm{I}$ & 0 & $\mathrm{I}$ \\
\hline
\end{tabular}

comprising protein..$^{45}$ Meal derived from krill is therefore high in protein and is also rich in $\omega-3$ fatty acids, which have been shown to have beneficial effects on fetal development and health of animals, including dogs. ${ }^{4-13}$ Although plant sources of protein are regularly analyzed for herbicides and pesticides, it is possible that they contain pesticides or herbicides that escape detection. Animal sources of protein may contain antibiotics or additional contaminants originating from the feed. Fish protein may contain higher than permissible levels of heavy metals or hydrocarbons, as certain fish may bioaccumulate these substances. As Antarctic krill are harvested from a pristine environment and are at the base of the food chain, it is likely that they contain lower levels of environmental contaminants than other protein sources. As shown in this study, arsenic content of krill meal is $56 \%$ lower than fishmeal.

Mink is considered a good model for the evaluation of the nutritional aspects of feed ingredients for other mammals, including dogs, cats, and foxes. ${ }^{33,35,37,46}$ Fluorine, iodine, lead, mercury, coumarin, sodium monofluoroacetate, diethylstilbestrol (DES), dioxin, aflatoxin, zearalenone, and nitrosamines all cause their principal toxicity in the same target organs 

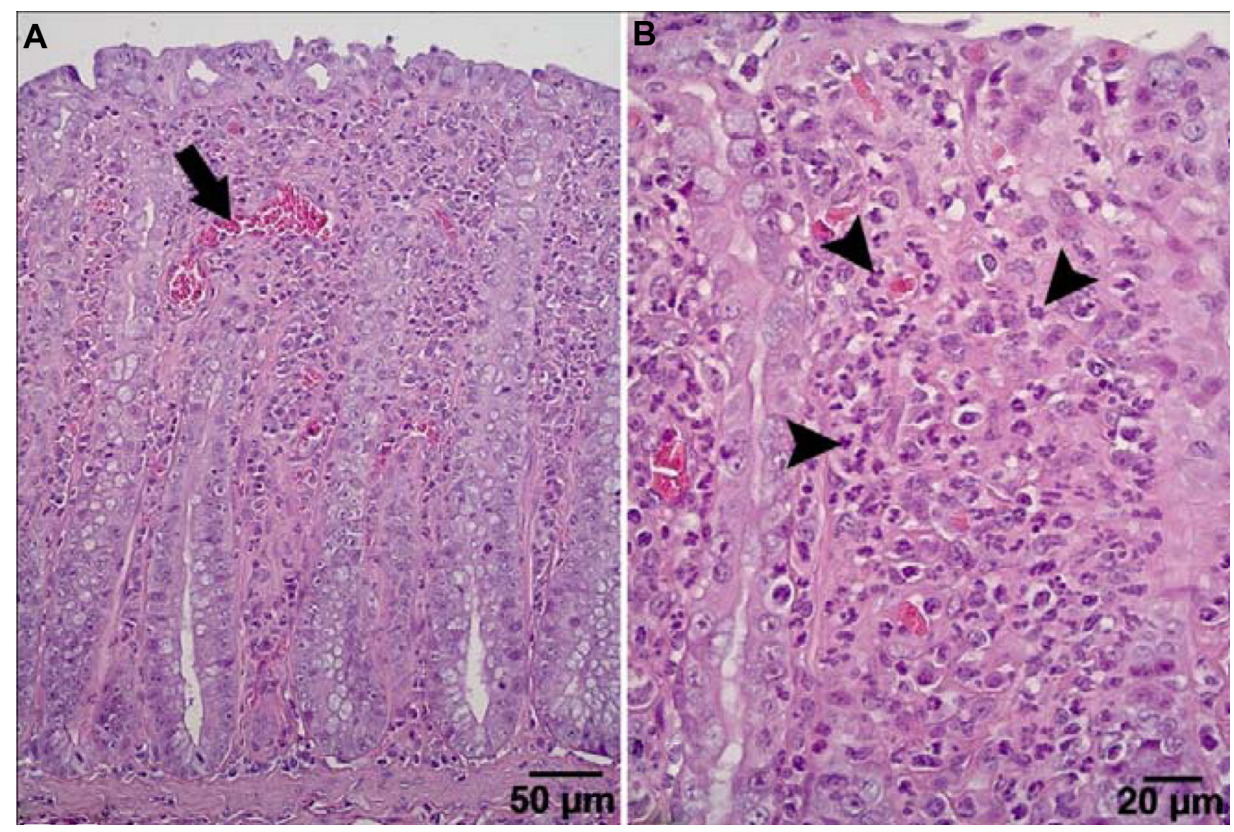

Figure I Example of rectum histology of a maternal animal from the K35 group. (A) Mild increase in blood flow to the epithelium, dilated blood vessel (arrow). (B) Marked increase in polymorphonuclear cells (arrowheads) within the lamina propria.

in mink as in other commonly encountered species. ${ }^{46}$ The current study using mink as a model animal for evaluation of Antarctic krill meal as a potentially new marine protein source for pet food focused on digestibility, reproductive performance, and health aspects of including the product at levels corresponding to $0 \%, 9 \%, 17 \%$, and $35 \%$ of dietary dry matter. The nutrient and amino acid composition of Antarctic krill meal was very similar to high-quality NorseLT 94 fishmeal. The protein digestibility of the Antarctic krill meal (85.0\%) was similar to that of low-temperature
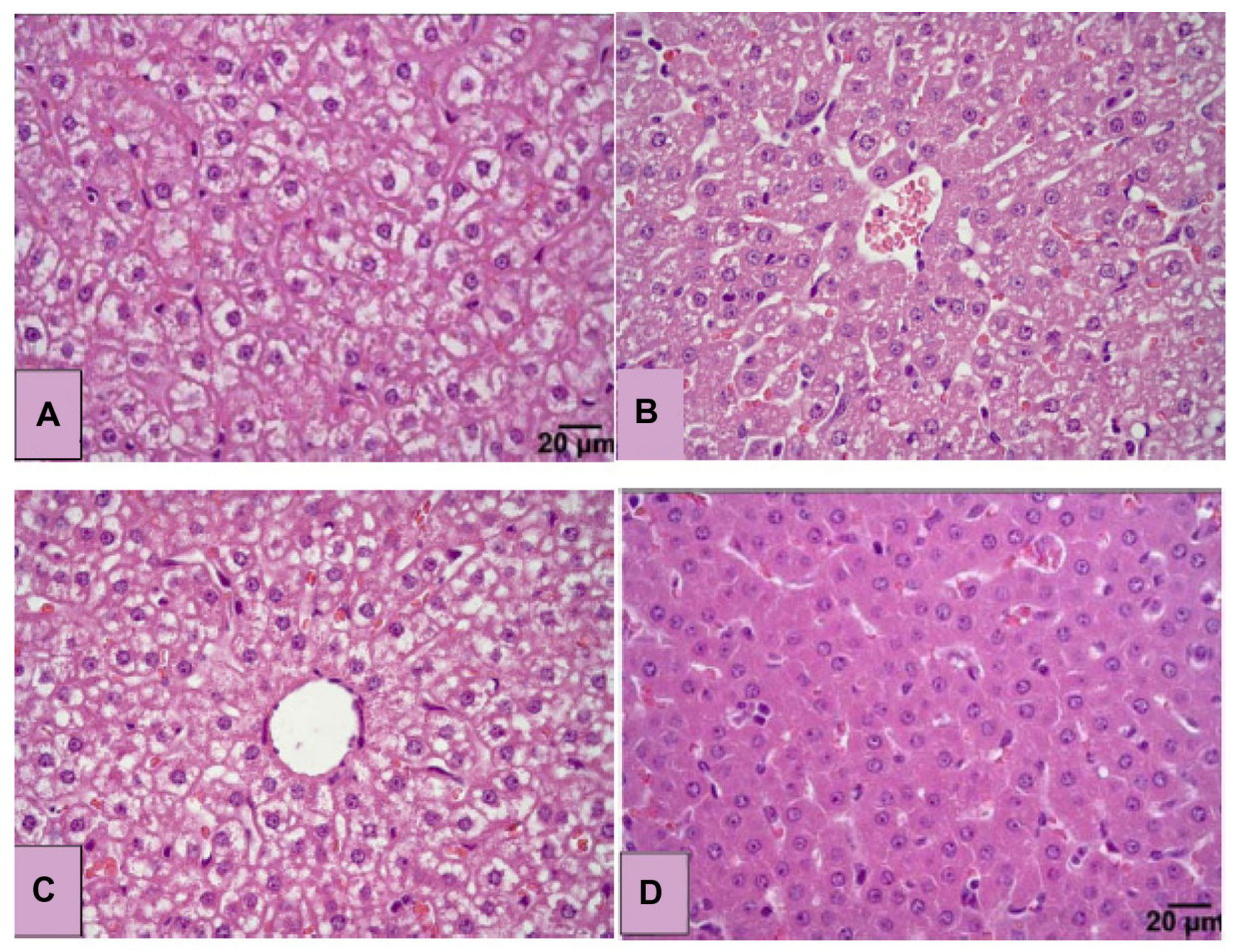

Figure 2 Examples of tissue histology of liver from maternal animals in the (A) K0, (B) K9, (C) KI7, and (D) K35 diet groups. Individuals from the K0 diet group had higher hepatocyte glycogen compared to individuals from the K35 group. 

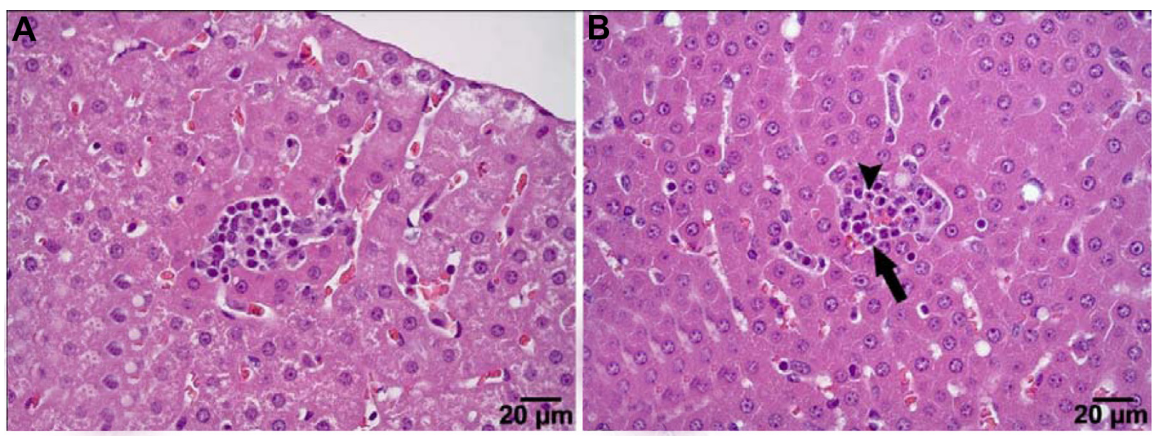

Figure 3 Example of a single focal leukocyte aggregation from an animal in $\mathrm{K} 0(\mathbf{A})$ and a multifocal leukocyte aggregation from an animal in $\mathrm{K} 35$ (B). In panel $\mathbf{B}$ apoptotic/ necrotic cells (arrowhead) are visible as well as polymorphonuclear cells (arrow).

fishmeal (87.0\%), and the estimated digestibility of the lipid fraction of the Antarctic krill meal diet was higher than that of soybean, assuming on the basis of previous experiments, a digestibility of $96.0 \%$ for soybean oil. ${ }^{38}$ This difference was most likely due to the higher degree of unsaturation of the fatty acids of the krill lipids. The results suggest that in mink, Antarctic krill meal is a highly digestible source of protein and lipid, comparable to fishmeal and superior to soybean.

In the reproduction experiment, there were no test material-related effects on maternal feed consumption, BW, survival, or reproductive performance. The rates of stillborn kits (1/302), singleton births (3/302), and survival to day 7 were within previously reported ranges. ${ }^{47,48}$ Kit survival until weaning, ranging from $88.6 \%$ in the $\mathrm{K} 17$ group to $95.7 \%$ in the $\mathrm{K} 0$ group, was also within the normal range. ${ }^{49}$ The highest initial litter size and the lowest average kit BW occurred in the K35 group. The low kit BW may be related to the well-known negative relationship between the litter size and weight of kits. However, the magnitude of the BW difference between kits in the $\mathrm{K} 35$ and $\mathrm{K} 0$ group at 49 days was significant (approximately 18\%). Kits start to eat solid feed at approximately 21 days of age, so after that time the growth rate is dependent on sufficient feed intake. The lower growth rate in the $\mathrm{K} 35$ group, especially between 21 days and weaning at 49 days, suggests that feed utilization was poorer with the K35 diet. A contributing factor could be the more frequent unrecorded feed spillage with this feed (which tended to be dry and crumbly), since feed consumptions were fairly similar for all groups.

In general, maternal animals tolerated all three inclusion levels of krill; however, some changes were observed in the K35 group compared to controls. Weights of the stomach and intestine were increased in the K35 group, an effect possibly related to the increased content of chitin in the K35 diet. Chitin, like other fibers, is expected to induce a physiologically normal adaptation with growth of gut tissue when included at high levels. Overall, the results indicate that some reduced or increased component(s) in the $\mathrm{K} 35$ diet stimulated the immune system of the animals, as indicated by the effects on WBC, platelet counts, and spleen weight. It is also possible that the effect on spleen weight was secondary to increased turnover of RBCs. ${ }^{50}$ Although a statistically significant decrease in RBCs was not observed in K35 animals, K35 individuals with lower than average RBC counts tended to have larger than average spleen weights. The reason for the
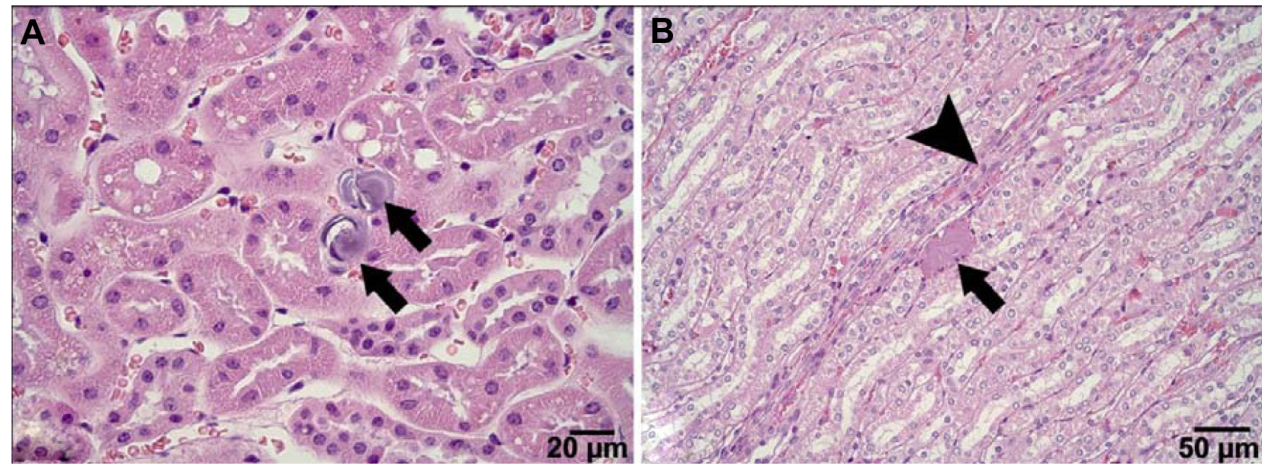

Figure 4 Example of crystalline material observed in the kidney of maternal animals from the K35 group. (A) Two crystalline deposits (arrows) adjacent to proximal convoluted tubules. (B) A single crystalline deposit (arrow) adjacent to a degenerated loop of Henle tubule (arrowhead). 
increased platelet count in K35 animals is unclear; however, animals with higher than average platelet counts tended to have lower than average RBC counts. The high average WBC count of K35 group mink was related to very high levels of neutrophils in a few animals, as reflected in the relatively high SD for this treatment. These results indicate that the highest krill level in the diet stimulated WBC proliferation in some but not all animals.

The anatomical and histological examinations did not reveal effects of krill inclusion in most tissues, with the exception of changes in the liver and gastrointestinal tract of the K35 group. The intestinal redness and rectal inflammation observed in some animals in the K35 group may be due to irritation from small shell fragments in the krill meal. It is also possible that some of the redness is due to staining by astaxanthin, a red-colored pigment present in krill. The lower glycogen level observed in the K35 compared to the $\mathrm{K} 0$ treatment did not have a histopathological correlate, and may indicate lower energy intake or assimilation, increased glycogenolysis, or a combination thereof. The fact that serum amylase was increased in the K35 group suggests that glycogenolysis was stimulated by inclusion of krill meal at the $35 \%$ level. The reason for the slight but statistically significant decrease in serum albumin in K35 animals is unclear, but it is likely not due to the slightly lower level of crude protein in the K35 diet compared to the $\mathrm{K} 0$ diet. The reason for the increased free fatty acids in plasma of mink fed with the K9, $\mathrm{K} 17$, or K35 diets is also unclear, but it may be a coincidence since the free fatty acids did not increase with the krill meal inclusion level.

It is altogether possible that the changes observed in the $\mathrm{K} 35$ animals were due to the differences in mineral content between the K35 and K0 diets. Although the amount of calcium in the K35 diet was lower than in the $\mathrm{K} 0$ diet, it was still higher than the amount of calcium typically present in mink feed $(7,500 \mathrm{mg} / \mathrm{kg}$, as fed $) .{ }^{51}$ Therefore, the effects noted in the K35 group were not likely to be due to calcium deficiency. As the levels of copper in the K35 diet were higher than the maximum levels allowed under EU regulations and the fluorine levels were also rather high, the alterations seen in the K35 group may be due to either or both of these substances. The concentration of copper in the krill meal in the present study (61 mg/ $\mathrm{kg} \mathrm{DM})$ was similar to the level found in previous krill meal studies. ${ }^{26,29}$ For copper, the European legal maximum for complete feeds is $25 \mathrm{mg} / \mathrm{kg} .{ }^{30}$ For the diets in our study, only the copper level of the diet with the highest krill meal inclusion (K35, $30.2 \mathrm{mg} / \mathrm{kg}$ ) exceeded this level. Aulerich et al ${ }^{52}$ examined effects of long-term (up to 357 days) copper supplementation on the health and reproduction of mink. The total dietary copper levels applied in the experiment were $60 \mathrm{mg} / \mathrm{kg}$, $132 \mathrm{mg} / \mathrm{kg}, 202 \mathrm{mg} / \mathrm{kg}, 345 \mathrm{mg} / \mathrm{kg}$, and $630 \mathrm{mg} / \mathrm{kg} \mathrm{DM}$; thus all levels were higher than the highest level applied in our study $(30.2 \mathrm{mg} / \mathrm{kg})$. Aulerich et $\mathrm{al}^{52}$ reported no toxicity or negative effects of any of the copper levels on mink, with the exception of a trend towards increased mortality of kits from birth to 4 weeks at dietary copper levels $\geq 202 \mathrm{mg} / \mathrm{kg} \mathrm{DM}$, and concluded that mink is among the species that are more tolerant to copper. Cats and dogs also tolerate relatively high copper levels in their feed. ${ }^{52}$ There are no reports of adverse effects of excess consumption of dietary copper in normal cats, ${ }^{53}$ and the maximum tolerable level of copper sulfate in dog food is $250 \mathrm{mg} / \mathrm{kg}$ feed, ${ }^{54}$ or $99.5 \mathrm{mg}$ copper $/ \mathrm{kg}$ feed, based on a molecular weight of copper sulfate of 159.6086 and copper of $63.546 .{ }^{55}$ Therefore, the amount of copper in the krill meal is not likely to cause toxicity to dogs or cats, even though it is higher than the maximum level allowed under EU regulations.

The fluoride concentration in the krill meal was found to be $2,004 \mathrm{mg} / \mathrm{kg} \mathrm{DM}$, which is considerably higher than the $940 \mathrm{mg} / \mathrm{kg} \mathrm{DM}$ value reported by Hansen et al. ${ }^{26}$ The reason for the difference is most likely natural variation. In Europe, the permissible levels of fluorine are $3000 \mathrm{mg} / \mathrm{kg}$ for feed materials from marine krill and $150 \mathrm{mg} / \mathrm{kg}$ for complete feeds containing $12 \%$ moisture. ${ }^{25}$ The latter is equivalent to $170 \mathrm{mg}$ fluorine/kg DM. The US FDA has not established a limit of fluorine in feed. The amount of fluoride in all krill meal diets applied in our study was higher than $170 \mathrm{mg} / \mathrm{kg}$ DM. Toxicity of fluoride in mink has been studied earlier by Aulerich et $\mathrm{al}^{56}$ in a dose-response experiment with the following levels: $0 \mathrm{mg} / \mathrm{kg}, 101 \mathrm{mg} / \mathrm{kg}, 184 \mathrm{mg} / \mathrm{kg}, 331 \mathrm{mg} / \mathrm{kg}$, $595 \mathrm{mg} / \mathrm{kg}$, and 1,073 mg/kg DM. No significant effects on gestation, litter size, or lactation were seen. The highest level seemed to cause a slight reduction in the survival rate at 3 weeks. No such effect was observed in the present experiment in which the diet with the highest fluorine level (K35) contained about $600 \mathrm{mg}$ fluoride/kg DM. Thus, while the fluoride content of the K35 diet was rather high, the findings are not consistent with the findings of previous studies examining the toxicity of fluoride in mink. Therefore, the toxicological findings in the K35 group cannot be solely attributed to fluoride.

\section{Conclusion}

In conclusion, results of the experiments indicate that Antarctic krill meal may replace high-quality fishmeal 
in diets for mink during the reproductive period at up to $17 \%$ based on biological characteristics such as palatability, feed intake, digestibility, reproduction, growth of the offspring during the lactation period, and maternal health parameters. Accordingly, the non-observable adverse effect level (NOAEL) assigned to the study is $17 \%$ (based on dry matter). Inclusion of $35 \%$ Antarctic krill meal in diets of pregnant mink was associated with decreased glycogen content of the liver, decreased plasma albumin, increased weights of the stomach and intestine, intestinal and rectal redness, rectal inflammation, increased WBC and platelet counts, and decreased BW of kits at weaning.

\section{Acknowledgments}

The authors would like to thank Arve Halstvedt, Torunn Osen, Marianne Brattberg, Ellen Hage, and Elvis Mashingaidze Chikwati for excellent technical assistance, and Signe Svindland and Line Johnsen for critical reading of the manuscript.

\section{Disclosure}

Aker BioMarine Antarctic AS, Oslo, Norway, provided the funding for the research project and publication of the manuscript. The authors report no other conflicts of interest.

\section{References}

1. Brown RG. Protein in dog foods. Can Vet J. 1989;30:528-531.

2. FAO. Euphausia superba (Dana, 1852). Food and Agriculture Organization of the United Nations (FAO), Fisheries and Aquaculture Department [Cited 2014]. Available from: http://www.fao.org/fishery/ species/3393/en. Accessed June 16, 2014.

3. Pierce RW, Van der Veen J, Olcott HS. Proximate and lipid analyses of krill (Euphausia species) and red crab (Pleuroncodes planipes). JAgric Food Chem. 1969;17:367-369.

4. von Schacky C, Angerer P, Kothny W, Theisen K, Mudra H. The effect of dietary omega-3 fatty acids on coronary atherosclerosis. A randomized, double-blind, placebo-controlled trial. Ann Intern Med. 1999;130:554-562.

5. Morris MC, Evans DA, Bienias JL, et al. Consumption of fish and n-3 fatty acids and risk of incident Alzheimer disease. Arch Neurol. 2003;60:940-946.

6. Alexander J, Froyland L, Hemre GI, et al. A Comprehensive Assessment of Fish and Other Seafood in the Norwegian Diet. Oslo: Norwegian Scientific Committee for Food Safety; 2006:1-173.

7. Iso H, Kobayashi M, Ishihara J, et al. Intake of fish and $n 3$ fatty acids and risk of coronary heart disease among Japanese: The Japan Public Health Center-Based (JPHC) Study Cohort I. Circulation. 2006;113:195-202.

8. Weitz D, Weintraub H, Fisher E, Schwartzbard AZ. Fish oil for the treatment of cardiovascular disease. Cardiol Rev. 2010;18: 258-263.

9. Brown SA, Brown CA, Crowell WA, et al. Effects of dietary polyunsaturated fatty acid supplementation in early renal insufficiency in dogs. J Lab Clin Med. 2000;135:275-286.

10. Ogilvie GK, Fettman MJ, Mallinckrodt $\mathrm{CH}$, et al. Effect of fish oil, arginine, and doxorubicin chemotherapy on remission and survival time for dogs with lymphoma: a double-blind, randomized placebo-controlled study. Cancer. 2000;88:1916-1928.
11. Freeman LM. Beneficial effects of omega-3 fatty acids in cardiovascular disease. J Small Anim Pract. 2010;51:462-470.

12. Roush JK, Dodd CE, Fritsch DA, et al. Multicenter veterinary practice assessment of the effects of omega-3 fatty acids on osteoarthritis in dogs. J Am Vet Med Assoc. 2010;236:59-66.

13. Abba C, Mussa PP, Vercelli A, Raviri G. Essential fatty acids supplementation in different-stage atopic dogs fed on a controlled diet. J Anim Physiol Anim Nutr. 2005;89:203-207.

14. Rees CA, Bauer JE, Burkholder WJ, Kennis RA, Dunbar BL, Bigley KE. Effects of dietary flax seed and sunflower seed supplementation on normal canine serum polyunsaturated fatty acids and skin and hair coat condition scores. Vet Dermatol. 2001;12:111-117.

15. Re S, Zanoletti M, Emanuele E. Aggressive dogs are characterized by low omega-3 polyunsaturated fatty acid status. Vet Res Commun. 2008;32:225-230.

16. Maki KC, Reeves MS, Farmer M, et al. Krill oil supplementation increases plasma concentrations of eicosapentaenoic and docosahexaenoic acids in overweight and obese men and women. Nutr Res. 2009;29:609-615.

17. Tandy S, Chung RWS, Wat E, et al. Dietary krill oil supplementation reduces hepatic steatosis, glycemia, and hypercholesterolemia in highfat-fed mice. J Agric Food Chem. 2009;19:9339-9345.

18. Ierna M, Kerr A, Scales H, Berge K, Griinari M. Supplementation of diet with krill oil protects against experimental rheumatoid arthritis. BMC Musculoskelet Disord. 2010;11:136.

19. Ulven SM, Kirkhus B, Lamglait A, et al. Metabolic effects of krill oil are essentially similar to those of fish oil but at lower dose of EPA and DHA, in healthy volunteers. Lipids. 2010;46:37-46.

20. Ferramosca A, Conte L, Zara V. A krill oil supplemented diet reduces the activities of the mitochondrial tricarboxylate carrier and of the cytosolic lipogenic enzymes in rats. J Anim Physiol Anim Nutr. 2012;96:295-306.

21. Berge K, Musa-Veloso K, Harwood M, Hoem N, Burri L. Krill oil supplementation lowers serum triglycerides without increasing lowdensity lipoprotein cholesterol in adults with borderline high or high triglyceride levels. Nutr Res. 2014;34:126-133.

22. Boone RJ, Manthey M. The anatomical distribution of fluoride within various body segments and organs of Antarctic krill (Euphausia superba Dana). Arch Fischereiwiss. 1983;34:81-85.

23. Zhang H, Jianming P, Xianhao C, Biying Z. Biogeochemistry research of fluoride in Antarctic Ocean I. The study of fluoride anomaly in Antarctic krill. Antarct Res. 1993;4:55-61.

24. SoevikT, Braekkan OR. Fluoride inAntarctic krill (Euphausia superba) and Atlantic krill (Meganyctiphanes norvegica). Can JFishAquat Sci. 1979;36: 1414-1416.

25. EC. Eur-lex.europa.eu. Fluorine. Commission Directive 2008/76/EC of 25 July 2008 amending Annex I to Directive 2002/32/EC of the European parliament and of the Council on undesirable substances in animal feed. [Cited 2008]. Available from: http://eur-lex.europa.eu/ legal-content/EN/TXT/PDF/?uri=CELEX:32008L0076\&qid=139949 7047743 \& from=EN. Accessed June 18, 2014.

26. Hansen JØ, Penn M, Øverland M, et al. High inclusion of partially deshelled and whole krill meals in diets for Atlantic salmon (Salmo salar). Aquaculture. 2010;310:164-172.

27. Tharanathan RN, Kittur FS. Chitin - the undisputed biomolecule of great potential. Crit Rev Food Sci Nutr. 2003;43:61-87.

28. Van Holde KE, Miller KI. Hemocyanins. Adv Protein Chem. 1995;47:1-81.

29. Locarnini PSJ, Presley BJ. Trace element concentrations in Antarctic krill, Euphausia superba. Polar Biol. 1995;15:283-288.

30. EC. Eur-lex.europa.eu. Copper. Commission Regulation (EC) No 1334/2003 of 25 July 2003 amending the conditions for authorization of a number of additives in feedingstuff belonging to the group of trace elements. [Cited 2003]. Available from: http://eur-lex.europa. eu/legal-content/EN/TXT/PDF/?uri=CELEX:32003R1334\&qid= 1399497573924\&from=EN. Accessed June 18, 2014.

31. Opstvedt J, Nygard E, Samuelsen TA, Venturini G, Luzzana U, Mundheim H. Effect on protein digestibility of different processing conditions in the production of fish meal and fish feed. J Sci Food Agric. 2003;83:775-782. 
32. Ahlstrøm Ø, Krogdahl Å, Vhile SG, Skrede A. Fatty acid composition in commercial dog foods. J Nutr. 2004;134:2145S-2147S.

33. Krogdahl $\AA$, Ahlstrøm Ø, Skrede A. Nutrient digestibility of commercial dog foods using mink as a model. J Nutr. 2004;134: 2141S-2144S.

34. Hellwing ALF, Tauson A, Ahlstrom O, Skrede A. Nitrogen and energy balance in growing mink (Mustela vison) fed different levels of bacterial protein meal produced with natural gas. Arch Anim Nutr. 2005;59: 335-352.

35. Tjernsbekk MT, Tauson AH, Ahlstrøm Ø. Ileal, colonic and total tract nutrient digestibility in dogs (Canis familiaris) compared with total tract digestibility in mink (Neovison vison). Arch Anim Nutr. 2014;68(3): 245-261.

36. Skrede A, Krogdahi A, Austreng E. Digestibility of amino acids in raw fish flesh and meat-and-bone meal for the chicken, fox, mink and rainbow trout. Z Tierphysiol Tierernahr Futtermittelkd. 1980;43:92-101.

37. Ahlstrøm Ø, Skrede A. Comparative nutrient digestibility in dogs, blue foxes, mink and rats. J Nutr. 1998;128:2676S-2677S.

38. Rouvinen-Watt K, White MB, Campbell R. Appendix B. Mink Feeds and Feeding: Applied Feeding Guide and Mink Feed Ingredient Database. Vol 174. Ottawa, ON: Ontario Ministry of Agriculture and Food, through the Agricultural Research Institute of Ontario, Nova Scotia Agricultural College; 2005:177.

39. EC. Amino acids. Commission Directive 98/64/EC of 3 September 1998 establishing Community methods of analysis for the determination of aminoacids, crude oils and fats, and olaquindox in feedingstuffs and amending Directive 71/393/EEC. [Cited 1998]. Available from: http:// eur-lex.europa.eu/legal-content/EN/TXT/PDF/?uri=CELEX:31998L0 064\&qid=1399497859635\&from=EN. Accessed June 18, 2014.

40. NMKL. Metals: Determination by Atomic Adsorption Spectrophotometry After Wet Digestion in Microwave Oven, NMKL Method No 161; 1998. Available from: http://www.nmkl.org/index.php?option=com_ zoo\&task $=$ item\&item_id $=334 \&$ Itemid $=319 \&$ lang $=$ en. Accessed November 18, 2014.

41. Malde KM, Bjorvatn K, Julshamn K. Determination of fluoride in food by the use of alkali fusion and fluoride ion-selective electrode. Food Chem. 2001;73:373-379.

42. Conway EJ. Microdiffusion Analysis and Volumetric Error. London, England: Crosby Lockwood and Son; 1957:90-162.

43. Ǿstergaard AFJ. Minkavler: black er minken for mig [Mink breeder: I prefer the black mink]; 2013. Available from: http://issuu.com/kopenhagenfur/docs/6051_dansk_pelsdyravl_nr6_2013_low/1. Accessed July $10,2014$.
44. Mustonen AM, Pyykonen T, Paakkonen T, et al. Adaptations to fasting in the American mink (Mustela vison): carbohydrate and lipid metabolism. Comp Biochem Physiol A Mol Integr Physiol. 2005;140:195-202.

45. Storebakken T. Krill as a potential feed source for salmonids. Aquaculture. 1988;70:193-205.

46. Calabrese EJ, Aulerrich RJ, Padgett GA. Mink as a predictive model in toxicology. Drug Metab Rev. 1992;24(4):559-578.

47. Einarsson EJ. Selection for litter size in mink II: direct response in litter size at birth. Norw J Agric Sci. 1987;1:155-178.

48. Lagerkvist G, Johansson K, Lundeheim N. Selection for litter size, body weight, and pelt quality in mink (Mustela vison): correlated responses. J Anim Sci. 1994;72:1126-1137.

49. European Commission (EC). The Welfare of Animal Kept for fur Production. [Cited 2001]. Available from: http://ec.europa.eu/food/animal/ welfare/international/out67_en.pdf. Accessed June 16, 2014.

50. Mebius RE, Kraal G. Structure and function of the spleen. Nat Rev Immunol. 2005;5:606-616.

51. Stejskal SM, Aulerich RJ, Slanker MR, Braselton WE, Lehning EJ, Napolitano AC. Element concentrations in livers and kidneys of ranch mink. J Vet Diagn Invest. 1989;1:343-348.

52. Aulerich RJ, Ringer RK, Bleavins MR, Napolitano A. Effects of supplemental dietary copper on growth, reproductive performance and kit survival of standard dark mink and the acute toxicity of copper to mink. J Anim Sci. 1982;55:337-343.

53. NRC Copper, Minerals. National Research Council of the National Academies. Nutrient Requirements of Dogs and Cats. Washington DC: The National Academies Press; 2006:171-173.

54. Aldrich G. Copper sulfate: a standard of reference for copper in petfood. [Cited 2014]. Available from: http://www.petfoodindustry. com/Sub_Level_-_News/Copper_sulfate_A_standard_of_reference_ for_copper_in_petfood.html. Accessed June 18, 2014.

55. Molecular Mass Calculator [webapge on the Internet]. WebQC.Org: 2014. Available from: http://www.webqc.org/mmcalc.php. Accessed May 30, 2014

56. Aulerich RJ, Napolitano AC, Bursian SJ, Olson BA, Hochstein JR. Chronic toxicity of dietary fluoride in mink. J Anim Sci. 1987;65: 1759-1767.

57. Hansen N, Finne L, Skrede A, Tauson A. Energiforsyningen hos mink og ræv [Energy supply in mink and foxes]. NJF-report No. 63. DSR Forlag: Copenhagen; 2001.
Open Access Animal Physiology

\section{Publish your work in this journal}

Open Access Animal Physiology is an international, peer-reviewed, open access journal publishing original research, reports, reviews and commentaries on all areas of animal physiology. The manuscript management system is completely online and includes a very

\section{Dovepress}

quick and fair peer-review system. Visit http://www.dovepress.com/ testimonials.php to read real quotes from published authors. 